\section{B A Institute of \\ YK Business Administration \\ 六下 \\ Karachi \\ Leadership and Ideas for Tomorrow}

Business Review

Volume 4 Issue 2 July-December 2009

7-1-2009

\title{
Foreign direct investment and labour productivity in Nigeria's manufacturing sector
}

Nasiru Musa Yauri

Usmanu Danfodiyo University Sokoto, Nigeria

Follow this and additional works at: https://ir.iba.edu.pk/businessreview

Part of the Business Commons

(c) (i)

This work is licensed under a Creative Commons Attribution 4.0 International License.

\section{Recommended Citation}

Yauri, N. M. (2009). Foreign direct investment and labour productivity in Nigeria's manufacturing sector. Business Review, 4(2), 37-54. Retrieved from https://doi.org/10.54784/1990-6587.1330

This article is brought to you by iRepository for open access under the Creative Commons Attribution 4.0 License and is available at https://ir.iba.edu.pk/businessreview/vol4/iss2/4. For more information, please contact irepository@iba.edu.pk. 


\title{
ARTICLE
}

\section{Foreign Direct Investment and Labour Productivity in Nigeria's Manufacturing Sector}

\author{
Nasiru Musa Yauri \\ Usmanu Danfodiyo University \\ Sokoto, Nigeria
}

\begin{abstract}
This paper investigates the relationship between Foreign Direct Investment (FDI) and labour productivity. The paper is able to clarify whether employees of foreign firms record significantly higher productivity levels than their counterparts in domestic firms in Nigeria's manufacturing sector. Using data from the World Bank Nigerian Manufacturing Survey 2001, employing an Ordinary Least Squares (OLS) regression model run on STATA, the paper finds that employees in foreign firms exhibit higher levels of productivity than their counterparts in domestic manufacturing firms. On the basis of this finding, the paper speculates on whether the differential is as a result of better training by foreign firms or due to greater capital intensity and better technology available to foreign firms. There is need for further research to substantiate these speculations. Result from this study did not reveal which of these factors is responsible for the difference in the labour productivity between domestic and foreign firms in Nigeria's manufacturing factor. There is also no existing study to show that the difference in the productivity levels of foreign and domestic firms in Nigeria's manufacturing sector is explained by the presence of more training, capital and technology in the former.
\end{abstract}

\section{INTRODUCTION}

Whether foreign direct investment (FDI) is associated with higher levels of labour productivity is relevant in explaining the relationship between FDI and host economies. It is also relevant in explaining the relationship between FDI and domestic firms. It is yet relevant in the determination and application of policy regimes aimed at attracting FDI, especially in less developed countries that hope to receive multiple benefits (investment finance, technology, skills etc.) from the inflow of FDI. It explains the role of foreign direct investment in the transfer of technology and skills in host economies both in FDI-recipient firms and their counterparts that are fully owned by domestic entrepreneurs. All these are particularly important in technology and knowledgescarce economies like Nigeria where the dearth of technology and the knowledge and skills to manage it have significantly retarded the growth of a viable local manufacturing industry. Anyanwu (2002) agree that the decline in productivity and capacity utilisation in the manufacturing sector could be explained by low level of technology, low investments, and high cost of production, inflation and poor performing infrastructures. 
Research on the effects of FDI in recipient countries has presented different outcomes on the relationship between FDI and labour productivity. Whereas some report that FDI has provided domestic employees and entrepreneurs with new skills (Djankov and Hoekman, 1999; Sousa 2001; and Gorg, Strobl and Walsh, 2002 among others), others report that clear evidence of such a relationship does not exist.

This paper contributes to empirical research on the effects of FDI on recipient economies. It investigates the effects of FDI on domestic firms that are recipients of foreign investment. The paper sets to determine whether foreign investment is associated with improvements in labour and managerial skills. The paper assumes that to investigate whether FDI is positively associated with improvement in the capacity of labour, it is appropriate to investigate whether FDI is positively related to labour productivity. In its approach to the problem, the paper tested for any significant relationships between the presence of FDI in some Nigerian manufacturing firms and the productivity of employees in those firms. This is done in comparison to productivity levels of employees in domestic firms in the same industry. If the results exhibit higher levels of labour productivity in FDI-recipient firms, then it is important to ask, why are employees more productive in foreign firms than in their domestic counterparts in Nigeria's manufacturing sector? Is it because foreign firms employ more effective corporate governance than their domestic counterparts? Or is it that employee motivation due to better remuneration and good working conditions is better in foreign firms? Or perhaps because employees in foreign firms employ better technology and work tools than their counterparts in domestic firms? Or is it merely because foreign firms have more access to financial capital than their domestic counterparts? Thus, from the outcome of the empirical analysis, the paper attempts to proffer some explanations on why foreign firms exhibit higher labour productivity than their domestic counterparts. In doing so, the paper relies on the outcomes of some empirical studies that tend to provide relevant explanations.

The paper is presented in five sections. After this introduction, the paper examines the nexus of FDI and domestic economies, particularly developing countries. That was followed by a review of empirical evidence on the relationship between FDI and firm performance in recipient economies. Section four is an explanation of the methodology employed in the study. After the methodology, the paper presents the results of the data analysis and interpretations of the results. The last section is summary and conclusions.

\section{Foreign Direct Investment and Domestic Economies- A Review of the Nexus}

The presence and activities of multinational corporations in the developing world has been the subject of controversy in development policy. It is noteworthy, however, that the theoretical background for the negative verdict on the effect of foreign investment on developing economies is largely from the ideological left (for example, the peripheral capitalism and Latin American dependency theories). The skepticism 
shown is often partly based on negative effects of the late 1960s and early 1970s, with blatant examples of incorrect behaviour e.g. inappropriate influence on political decisions, exploitative wages and poor social conditions. In recent years, the impact on developing countries of multinational corporations has been judged more favourably. More recent comparative surveys by the International Labour Organisation (ILO: 1981) of social conditions, effects of employment and training by multinationals and local companies paint a positive picture for multinationals.

It is true however, that up till today, a matter of concern to experts on global economic integration, global trade and development policy is whether the global movement of financial capital impacts positively on recipient economies. Whereas various studies have investigated the effects of FDI on specific firms, sectors and segments of recipient countries; research on the aggregate effects of FDI on recipient economies is rather scarce. This has made it difficult for the resolution of the disagreement on the aggregate effect of FDI on host economies. Not all economists, therefore, agree that the aggregate effect of FDI on developing countries is positive. Girma (2005), for example, is of the view that while increased economic integration has given rise to FDI with host economies benefiting from increases in living standards, one should still remain cautious of the often observed positive correlation between inward FDI and subsequent increases in economic growth since this does not necessarily imply a causal relationship. Girma's caution, however, is not a conclusion that such positive correlation between FDI and growth in host economies generally, and specifically in domestic firms does not exist. This is because, as mentioned earlier, despite the nexus between FDI and host economies (particularly developing countries), many studies have found that host economies stand to gain from the inflow of FDI.

This explains why in their quest to attract a larger share of global FDI flows, many developing countries especially those in Sub-Saharan Africa (SSA) have over the past decade or two carried out series of economic reforms aimed at increasing the role of the private sector in development. They have opened up their economies to foreign investment by eliminating various types of regulatory barriers (Obwona: 2004). Vo and Batten (2006) agree that to capture many of the economic benefits arising from international integration, many countries-especially developing countries-are undertaking reform agendas designed to improve the efficiency and scope of their domestic financial systems and remove structural impediments that may retard cross-border flows. The United Nations Conference on Trade and Development, UNCTAD (1999) reported that by 1999, Nigeria has signed six (6) bilateral investment treaties (BITs) and eleven (11) double-taxation treaties (DTTs) aimed at encouraging the inflow of FDI. The focus of this paper is on whether manufacturing firms in Nigeria stands to benefit from the inflow of FDI, especially through increases in labour productivity.

A reasonable number of empirical studies on the relationship between FDI and host economies show that the efforts of the developing countries will be rewarded in 
the long run. Studies indicate that while some policy makers remain circumspect about the long term benefits arising from inward (or inbound) portfolio investment, often citing the dangers to domestic financial system stability arising from its speculative component, there is a general consensus that FDI, by virtue of its longer term nature, has a more favourable economic impact (Vo and Batten, 2006).

At the macroeconomic level, the influx of FDI has been generally associated with technology transfer and GDP growth in host economies (Lipsey, 2000; Dees, 1998; De Mello, 1997). In this regard, FDI contributions to growth comes through its role as a conduit for transferring advanced technology from industrialized to developing countries (Dimelis, 2005; Schneider, 2005 as cited by Vo and Batten: 2006). It has also been shown that FDI boost economic growth through productivity gains, and the introduction of new processes, managerial skills and know-how in the host countries (Girma, 2005; Li and Liu, 2005 as cited by Vo and Batten: 2006).

In addition to all of the above are the traditional arguments in favour of multinational activities and FDI in developing countries. In this argument, it is proffered that there exist gaps which inhibit the rate of growth in the less developed countries. It is argued that multinational corporations and FDI are beneficial to economic development in the less developed countries because they help in filling these gaps. According to Todaro (1981:403) the pro-foreign investment arguments grow largely out of the traditional neoclassical analysis of the determinants of economic growth. Foreign private investment (as well as foreign aid) is typically seen as a way of filling in gaps between domestically available supplies of savings, foreign exchange, government revenue and skills, and the planned levels of these resources necessary to achieve development targets. This is better explained using the Harrod-Domar model. Using the HarrodDomar growth model, it is explained that there is a direct relationship between a country's rate of savings and its rate of output growth. The model postulates a direct relationship between a country's rate of savings, $\mathrm{s}$, and its rate of output growth, $\mathrm{g}$, through the equation, $\mathrm{g}=\mathrm{s} / \mathrm{k}$, where $\mathrm{g}$ is the expected rate of output growth, $\mathrm{s}$ is the rate of savings and $\mathrm{k}$ is the national capital-output ratio. Thus, if a country targets a $7 \%$ rate of output growth, and if its capital output ratio is $3 \%$, then the required rate of savings to finance the growth is $21 \%(\mathrm{~s}=\mathrm{g} \times \mathrm{k}$ ). If the locally mobilised savings is only $11 \%$ then there is a savings-investment gap of $10 \%$ which can be financed by foreign resources. Thus, FDI fill this gap between targeted investment and locally mobilised savings. By so doing, FDI facilitate economic growth and development in the less developed countries.

Despite the fact that the gap-filling arguments date back to the early 1970s, research has continued to show that most developing economies still experience shortages in savings, foreign exchange, government revenue, labour and managerial skills. Thus, the gap-filling arguments are still plausible explanations on the benefits of FDI and multinationals to developing countries. 


\section{FDI and Firm Performance in Host Economies- A Review of Empirical Evidence}

The possibility that firms will perform better when they receive FDI is sufficient motivation for developing countries to want to attract FDI. The tendency of FDI to influence productivity levels in Nigeria's manufacturing sector is sufficient motivation for the Nigerian government and the association of manufacturers in Nigeria (MAN) to want to attract increased FDI in the sector. This is especially because the sector has for a long period of time been suffering from low productivity and low capacity utilization. This has been adequately reported by scholars (Table 1). Adhoc studies conducted by Akinlo (1996) also indicated that, on the average, there was little rise in productivity in Nigerian manufacturing during the time of study. In a study of the productivity of food and basic metal industries in Nigeria, only 30 percent of respondents indicated they had rising productivity. About 11 percent recorded no growth, while more than half, 57 percent, recorded declining productivity levels. Anyanwu (2002) has studied the growth rate in the manufacturing sector from a historical perspective and found that growth rate in the sector was relatively high in the period 1966-75 at an annual average of 12.9 percent. Growth in the sector expanded in the period 1976-85 with the establishment of more import substitution industries, with an annual average growth of 18.5 percent. However, with the collapse of the world oil market from the early 1980s and drastically reduced foreign exchange earning capacity, the sub-sector was no longer able to import needed inputs. Hence, manufacturing output growth fell drastically to an annual average of about 2.6 percent during 1986-98, even with the introduction of Structural Adjustment Programme (SAP) in 1986. For the period 1993-98, growth in the sector was negative.

From the sample of studies cited above, it is evident that domestic manufacturing firms in Nigeria have suffered from declining productivity and low growth rates. On whether FDI is a panacea, however, evidence must indicate whether or not there is difference in the productivity levels between firms that receive FDI and those that do not. Majority of researches that support the existence of positive complementarities between foreign and domestic firms, assert that these complementarities essentially enhance the productive abilities of domestic firms.

Obwona (2004) argue that for domestic firms, the contagion effect or knowledge diffusion can lead to improvements in productivity and efficiency of local firms. Many empirical works have proven to that effect. For example, Yauri (2006) found that domestic firms that receive FDI in Nigeria's manufacturing sector benefit from technology transfer. In similar findings, many other studies have found positive complementarities between FDI and domestic firms. A number of researches find that foreign direct investment is a source of technology transfers between foreign and domestic firms in some countries. Scholars who arrive at this finding suggest that technology transfer is one of the positive effects of foreign direct investments because it enhances the productive abilities of domestic firms. 
In a comprehensive study, Kinoshita (1998) explains there are four channels through which FDI can possibly affect the productivity of local firms through technology transfer.

First, is the demonstration effect; or contagion-imitation effect. This is supported by Kokko (1994). In explaining the demonstration effect; differences exist in the levels of technology between foreign and local firms. Foreign firms with more advanced technologies enter a local market and introduce newer technologies to the industry. Through direct contact with foreign affiliates, local firms can watch and imitate the way foreigners operate and can therefore become more productive. This may also occur through a labour turnover from foreign to local firms in which case, employees from foreign firms are employed by domestic firms and they bring with them knowledge of new technologies employed by their former employers. The existence of this kind of channel is recognised by Findlay (1978), Koizumi and Kopecky (1977) and Das (1987). And importantly, this is the one of the conduit through which technology brought by foreign direct investments can benefit domestic firms, regardless of whether the firms are recipients of FDI or not.

Gorg and Greenaway (2004) agree with Kinoshita (1998) that imitation is the classic transmission mechanism for new products and processes. One mechanism writers commonly allude to in the theoretical literature on technology transfer from developed to developing economies is reverse engineering as supported by Das (1987) and Wang and Blomstrom (1992). The scope of reverse engineering depends on the complexity of products and processes, with simple manufactures easier to imitate than more complex ones.

Secondly, the competition effect may occur as follows: the entry of foreign firms lead to more intense competition in the local industry and local firms are forced to be more efficient in using existing technologies and resources (Kinoshita, 1998). Local firms may also have to introduce new technologies by themselves in order to maintain market shares. Increased competition may be able to eliminate monopolistic profits and enhance the welfare of a host country. Many scholars believe that through this channel, domestic firms that compete with foreign firms, their partners or subsidiaries are forced by the competition effect to adopt new and improved technical processes. Gorg and Greenaway (2004) agree that unless an incoming firm is offered monopoly status, it will produce in competition with indigenous firms which leads to a horizontal spillover of technology. They further explain that even if indigenous firms are unable to imitate the multinational's technology and production processes, entry of the multinational firm puts pressure on them to use existing technology more efficiently, yielding productivity gains.

Third, spillovers through backward and forward linkages may arise when foreign affiliates materialise transactions with local suppliers and customers. When the 
cost of communication and transportation is high, then the MNCs often choose to purchase intermediate goods from local producers. Foreign firms may provide technical assistance and training to local suppliers, or may assist them in purchasing raw materials so as to maintain the quality of intermediate goods. Even in the absence of such direct involvement, local suppliers are forced to meet demand for higher quality and on-time delivery and to innovate more (Kinoshita, 1998). This is the "backward linkages" effect. Backward linkage is encouraged in the presence of "local content requirements"- which means that foreign firms have to purchase a certain percentage of intermediate inputs in a host country instead of importing from suppliers abroad. It is also possible that technology spillovers occur through forward linkages. Kinoshita (1998) explain that in many industries in developing countries, as technical complexity increases, domestic producers may seek to purchase intermediaries from suppliers whose goods are superior to those obtained from local suppliers.

Fourth, the costly effort to train local workers lead to productivity improvements (Kinoshita, 1998); this is another technology effect of FDI. Many believed that training is an avenue through which FDI transfer technology to domestic firms. Kinoshita (1998) explains that this is referred to as the "training effect", in which case on-the-job training may be provided by foreign joint ventures partners, foreign buyers or suppliers leading to a vertical effect of FDI on domestic firms. Often local firms train their own workers to increase product quality in order to cope with foreign entrants with a competitive edge. The arrival of new technology alone may not create productivity growth in a host country unless the labour force builds up the corresponding skills. Jovanovic (1997) explains that technologies are laws of physics that are relevant to a particular way of producing something. These laws are described in blueprints. A blueprint, however, is an incomplete description of what it is useful to know about the technology at hand, this incompleteness creates a role for training and learning by doing as ways of building up the specific human capital. Thus, training which involves the accumulation of these skills is considered as an invaluable investment and an important ingredient in the transfer of technology since the skill acquired is specific to the technology.

In addition to the four broad avenues by which domestic firms might benefit via technology spillovers from FDI, is the effect of FDI on domestic firms (both vertical and horizontal) through the transfer of labour and or managerial skills. Results from various case studies indicate that domestic firms are likely to experience increased availability of skilled labour due to the presence of FDI.

Gorg and Strobl (2002) have noted that empirical work that investigates the effects of FDI on labour skills is scarce. They noted, however, that the International Labour Organisation, ILO (1981) and Lindsey (1986) have shown evidence that multinationals are important providers of training activities in developing countries. 
The evidence found in the literature support that there are basically two major avenues by which FDI is responsible for improvements in labour skills available to domestic firms. First, is through training and development in the case of vertical spillover effects, and second by labour mobility in the case of horizontal spillover. In the first instance, entry of FDI in domestic firms raises the intensity of training and development of employees in those firms. This is because, studies mostly found that in comparison of domestic firms to multinationals, their subsidiaries or partners, the latter provide more training than the former. Thus, firms that receive some FDI are likely to enjoy more skilled labour due to training and development or learning-by-doing. Djankov and Hoekman (1999) analyse enterprise level panel data for the Czech Republic and found that multinationals provide higher levels of training than domestic firms. Sousa (2001) also did a comprehensive analysis of the training activities of multinationals. Using detailed data of workplaces in the UK, he finds that multinationals are more likely to provide training; they also provide higher intensities of training than domestic firms. Narulla and Marin (2003) observed that multinational enterprises can cause direct increases in the quality of the domestic workforce by providing formal and informal training as well as through the process of learning-by-doing to transfer their superior technological knowledge to domestic employees.

Another avenue by which domestic firms receive labour skills from FDI is by labour mobility, when employees of FDI firms leave and join domestic firms wholly owned by entrepreneurs (horizontal spillovers). Gershenberg (1987) in a survey of 72 manufacturing firms in Kenya found evidence of movements of managers from multinationals to domestic firms. Also, Gorg, Strobl and Walsh (2002) using a matched firm and worker level data set for Ghanaian manufacturing firms show that the potential for labour spillover through the movement of highly trained and experienced workers from multinationals to domestic firms exist. Thus, when workers receive training or accumulate experience (learning-by-doing) working for multinationals, and then move to domestic firms or set up their own enterprise, a horizontal effect of FDI on labour skills is said to occur. When moving, such workers take with them some of the knowledge they have acquired in the multinational which can be usually employed by the domestic firm and help improve its performance. Aitken and Harrison (1999) agree with this explanation and buttress that, domestic firms might benefit from the presence of foreign firms because workers employed by foreign firms or participating in Joint Ventures may accumulate knowledge, which is valued outside the firm. As experienced workers leave the foreign firms, the human capital becomes available to domestic firms, raising their measured productivity.

Similarly, using sector level data, some studies have supported the findings that FDI brings improvements in labour skills. Blomstrom and Persson (1983) arrived at results to show that labour productivity was significantly higher in sectors which have a high concentration of foreign firms. Using firm level data, this study investigates whether FDI firms have higher labour productivity than domestic firms that are not recipients of FDI. 


\section{Methodology}

To test the relationship between FDI, domestic firms and labour productivity, the following hypotheses are postulated:

H1: $\quad$ FDI lead to increases in labour productivity

H2: Labour Productivity is significantly higher in FDI firms than in domestic firms

To test these hypotheses, there is need to define labour productivity and generate data on it ${ }^{1}$. A simple accounting procedure that is used to compute labour productivity is the one that relate sales to the number of employees in an organisation. Thus, an organisation's total sale at a point in time is divided by the number of employees in the organisation; the higher the ratio, the more efficient are the employees (labour) in an organisation. This is given as follows:

Labour Productivity $=\quad$ Sales

No. of employees.

The study tested for labour productivity at four year intervals for 1990, 1994, 1998 and 2000 .

The data used in this research was collected by the RPED Department of the World Bank in a survey research on Nigerian manufacturing firms conducted in 2001. A team of World Bank specialists conducting a survey of Nigerian manufacturing firms have administered questionnaires and interview modules on a sample of 232 firms in the Nigerian manufacturing sector. This sample of 232 was drawn from 9 sub-sectors of the Nigerian manufacturing sector, specifically chemical/paints, food/beverages, metal, non-metal, paper/printing/publishing, pharmaceuticals, plastics, textiles and wood sub-sectors (see table 3 for identities of sectors as employed in the regression model).

Also, the sample firms were selected from the three major geographical regions and industrial axis of Nigeria namely, East, Lagos and South and the North. The Lagos and South region had the highest share of the sample with 125 firms, North 60 and East 47. Of the firms in the sample, 102 had FDI at the time of the survey (represented in the model as ß2fdisurvey it), 130 are wholly owned by domestic entrepreneurs.

Gorg and Strobl (2002) similarly utilised the World Bank RPED Survey data for Ghanaian manufacturing firms for the period 1991-1997 in their study. Gorg and Strobl (2002) observed that the data set includes among other things, data on the level of output, total expenditures on wages, the replacement value of the capital stock, the level of value added, and the level of employment. More importantly, they noted that the data collection entails an intricate questionnaire on the background of the owner, or, in the case of a corporation, the chairman of the firm. Thus, the data sets reveal whether a firm is owned by foreigners through direct investment, a firm has received

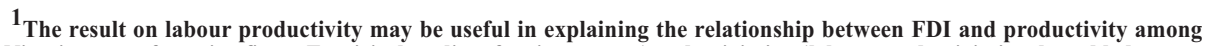
Nigerian manufacturing firms. Empirical studies often interprete 'productivity' as 'labour productivity', value added output per worker (Ferret, 2004)

2 me have access to the data, and to Giuseppe Iarossi and Giovanni Tanzillo of the World Bank RPED for the permission.
matiand, for initiating efforts to enable 
some amount of foreign investment or not at all. Specifically, according to Gorg and Strobl (2002) one is able to identify whether the owner/chairman has received any explicit training by foreign firms in the past, whether their immediate previous experience was working with a foreign firm within the same industry as the industry of their current firm or in some other industry, and whether they have had any previous same industry experience in general. Such is the kind of data available in the data set from a similar survey by the World Bank on Nigerian manufacturing firms.

Questions gen04b, gen04c, gen04d of the General Firm Questionnaire (RPED Nigerian Manufacturing Survey, 2001) generated data on the sales volume of the firms in the sample for the periods 1990, 1994, and 1998 respectively. Question gb15b of the Entrepreneurship Questionnaire generated data on the sales volume of the firms for the year 2000. On the other hand, questions lab01b, lab01c, lab01d and lab01f of the Labour Market Questionnaire asked responding firms to indicate their number of employees in 1990, 1994, 1998 and 2000 respectively. Thus, both questions generated exact estimates of the parameters. The study defined labour productivity for each year in question as the result of dividing that year's sales by the total number of employees (equation i). The study then employed OLS multiple regression to test the hypothesis. The regression equation is given as follows:

$$
\begin{aligned}
\text { Labprod }_{i t}= & a+\beta_{1} \text { fdistartup }_{i t}+\beta_{2} \text { fdisurvey }_{i t}+\beta_{3} \text { firmage }_{i t}+\beta_{4} \text { sectorid }_{i t} \\
& +\beta_{5} \text { region }_{i t}+\beta_{6} \text { firmsize }_{i t} \ldots \ldots \ldots \ldots \ldots \ldots \ldots \ldots \ldots . . . . .1 \text { (ii) }
\end{aligned}
$$

Where Lalprodit, is the dependent variable denoting Labour productivity of firm i, at time $\mathrm{t}$. $\mathrm{a}=$ an intercept

$\beta_{1}$ fdistartup $_{i t}=$ firm i that commenced business with FDI at time $\mathrm{t}(1 \mathrm{if}$ firm with FDI, 0 if none)

$\beta_{2}$ fdisurvey $_{i t}=$ firm $\mathrm{i}$ with FDI at the time of survey $\mathrm{t}(1$ if firm with FDI, 0 if none)

$\beta_{3}$ firmage $_{i t}=$ the age of firm $\mathrm{i}$ at the time of survey $\mathrm{t}$ (years)

$\beta_{4}$ sectorid $_{i t}=$ the sector of firm $i$ at the time of survey $(1=$ food and beverages sector, $0=$ otherwise)

$\beta_{5}$ region $_{i t}=$ the region where the firm $\mathrm{i}$ is located at time $\mathrm{t}(1=$ East, $0=$ otherwise $)$

$\beta_{6}$ irmsize $_{i t}=$ the size of firm $\mathrm{i}$, whether small-medium or large at time $\mathrm{t}$ ( 1 if large; 0 otherwise)

The variable $\beta_{2}$ fdisurvey $_{i t}$ test the hypotheses of the study; whether firms with some amount of foreign investment at the time of data collection record statistically 
higher Labour productivity than domestic firms. This variable enable the study to establish whether FDI increases labour productivity and whether firms with foreign direct investment perform record significantly higher labour productivity than firms without FDI. The two hypotheses in this study are thus tested using this model.

The variable $\beta_{1}$ fdistartup $_{i t}$ is included in the model to aid an acid test; whether firms set up with foreign investment $\beta_{1}$ fdistartup $p_{i t}$ perform better than firms that receive FDI at a later stage $\beta_{2}$ fdisurvey $_{i t}$. If firms established with FDI perform better than firms that receive FDI at a later stage (a duration model), then the finding will merely reinforce the hypotheses. Otherwise, evidence that firms with FDI at the time of the Nigerian Manufacturing Survey $\beta_{2}$ fdisurvey $_{i t}$ which includes firms in the first category $\beta_{1}$ fdistartup $_{i t}$ is sufficient to prove the hypotheses. The remaining variables are control variables to isolate the effects of firm age, the sector in which the firm operate, the region in which the firm is located and the size of the firm on labour productivity.

In the next section, the results of the regression analysis are presented.

\section{Results and Discussions}

The results of the regression analysis are summarised in table 2. Other results discernible from the table are briefly highlighted; the paper discusses details of results on the relationship between FDI, domestic firms and labour productivity.

Results on table 2 show a significantly positive relationship between FDI and labour productivity. From the results, FDI is significantly positively related to labour productivity in 1994, 1998 and 2000. In the years mentioned, the relationship between FDI and labour productivity is significant and positive (at $1 \%$ significance level). Thus, the hypotheses that FDI increases labour productivity and that labour productivity is higher in FDI firms than in non-FDI firms are accepted. Though firms that commenced business with FDI (fdistartup firms) do not show any significant relationship with labour productivity relative to non-FDI firms, all firms with some foreign investment at the time of the Nigerian Manufacturing Survey (fdisurvey firms) which also include firms in the first category are found to achieve higher labour productivity than domestic firms wholly owned by local entrepreneurs.

This result is significantly different from that of Djankov and Hoekman (1998) who found that although firm-level total factor productivity (TFP) growth in Czech firms is higher in firms with foreign partnerships, once common macroeconomic influence and industry effects are controlled for, foreign investment does not have a statistically significant positive impact on firm performance. Though the study controlled for firmlevel characteristics and industry/sectoral influences, it was found that labour productivity 
of firms that receive FDI is significantly higher than in firms wholly owned by domestic entrepreneurs. Blomstrom and Kokko (1996) explain this divergence of results. According to them, multinationals (and hence FDI) may play an important role for productivity and export growth in their host countries, but the exact nature of the impact of FDI varies between industries and countries, depending on country characteristics and the policy environment.

This result reinforces the findings in Yauri (2006) that FDI is associated with technology growth in domestic firms in Nigeria's manufacturing sector. Ferret (2004) had reasoned that, unless some aspect of technology changes, there is no reason for output to change. Thus, the evidence in this paper that FDI firms do exhibit higher levels of labour productivity than non-FDI firms in Nigeria's manufacturing sector further reinforces the previous finding that FDI is associated with technology transfer to Nigerian manufacturing firms. It follows that foreign firms are associated with greater capital intensity and technology, hence record higher labour productivity than domestic firms.

The result is also consistent with findings of the World Bank Nigerian Manufacturing Survey 2001. Marchat et al (2002) while commenting on the results stated that percentage of foreign equity in a firm is a highly significant determinant of productivity and the percentage of inputs imported is significant at the 5 percent level. However, their evidence points to the possibility of capital intensity since the amount of inputs imported by foreign firms is significant (at 5\%) in explaining the productivity of firms studied.

In addition, Marchat et al (2002) also noted that worker training and the incidence of technical assistance contracts and foreign licenses were not significant determinants. Thus, higher labour productivity among FDI firms in the Nigerian manufacturing sector may not be explained by higher training. It is interesting, however, to investigate whether Marchat et al (2002) and hence the RPED Survey on Nigerian manufacturing firms 2001 have considered all aspects of training, both off-the-job and on-the-job training; both formal and informal. Until it is determined if both aspects of training were considered in arriving at the conclusion by Marchat et al (2002), it will not be safe to conclude that worker training is not significant in explaining productivity among foreign firms in the Nigerian manufacturing sector.

The need for caution is reaching this particular conclusion is founded on the results of Gorg and Strobl and Walsh (2002) as discussed in section 3 of this paper. Gorg, Strobl and Walsh (2002) had studied the relationship between FDI and labour productivity among Ghanaian manufacturing firms at the same time investigating the potential for spillover to domestic firms. Using a matched firm and worker level data set for Ghanaian manufacturing firms they show that the potential for labour spillover through the movement of highly trained and experienced workers from multinationals to domestic firms exist. This happen when workers receive training or accumulate 
experience (learning-by-doing) working for multinationals, and then move to domestic firms or set up their own enterprise, a horizontal effect of FDI on labour skills is said to occur. Their results indicate that even without training, the process of learning by doing create potential for domestic firms to benefit from the skills acquired by workers formerly employed by foreign firms. When moving, such workers take with them some of the knowledge they have acquired in the multinational which can be usually employed by the domestic firm and help improve its performance. Aitken and Harrison (1999: 607) agree with this explanation and buttress that, domestic firms might benefit from the presence of foreign firms because workers employed by foreign firms or participating in Joint Ventures may accumulate knowledge, which is valued outside the firm. As experienced workers leave the foreign firms, the human capital becomes available to domestic firms, raising their measured productivity.

\section{Summary and conclusion}

This paper establishes a positive relationship between foreign investment and labour productivity among Nigerian manufacturing firms. The paper also found that firms with some amount of FDI record significantly higher labour productivity than wholly owned domestic firms.

Whether firms that are wholly owned by local entrepreneurs will benefit from this relationship due to labour spillovers (as employees of FDI firms move to domestic firms) is an area for further research. The chance however, that employees of firms that are recipients of FDI will eventually take up employment with domestic firms exist. This will eventually translate to increased labour productivity by domestic firms. This is especially likely if higher labour productivity in FDI-firms is due to the fact that they do more training than domestic firms; then labour mobility from FDI-firms to domestic firms will translate to higher productivity among domestic firms. However, if the reason for higher labour productivity in the FDI-recipient firms is capital intensity, then the likelihood is that even when employees from FDI-firms move to domestic firms, the productivity of domestic firms may not rise due to variation in capital intensity. This is because the skills acquired by workers formerly employed by foreign firms but move to domestic firms may be ineffective because domestic firms operate at lower levels of capital intensity than foreign firms. A research on the avenues for spillover between foreign and domestic firms in Nigeria's manufacturing sector is required to confirm which of the relationship above is likely to occur.

\section{REFERENCES}

Adedipe, B. 2004 The Impact of Oil on Nigeria's Economic Policy Formulation, paper presented at the conference on "Nigeria: Maximising Pro-poor Growth: Regenerating the Socio-economic Database", organized by Overseas Development Initiative (ODI) in collabouration with the Nigerian Economic Summit Group, June 16-17 2004. 
Aitken, B.J., and Harrison, A., 1999 Do Domestic Firms Benefit from Foreign Direct Investment? Evidence from Venezuela, The American Economic Review, June , 89(3): pp 605-18.

Akinlo, E.A., 1996 Improving the Performance of the Nigerian Manufacturing Subsector after Adjustment, The Nigerian Journal of Economics and Social Studies.

Anyanwu, C.M., 2002 Productivity in the Nigerian Manufacturing Sector, www.cenbank.org.

Blomstrom, M., and Persson, H., 1983 Foreign Investment and "spillover" efficiency in an underdeveloped economy: Evidence from the Mexican manufacturing industry, World Development, 11, June: pp 493-501.

Das, S., 1987 "Externalities, and technology transfer through multinational corporations: a theoretical analysis", Journal of International Economics, vol. 22, pp 171-82.

De Mello, L.R. 1997 Foreign direct investment in developing countries and growth: A selective survey, Journal of Development Studies, 34(1): pp 1-34.

Dees, S. 1998 Foreign direct investment in China: Determinants and effects' Economics of Planning, 31: pp 175-94.

Djankov, S., and Hoekman, B., 1999 Foreign Investment and Productivity Growth in Czech Enterprises, World Bank Economic Review, vol. 14: pp 49-64

Ferret, B., 2004 Foreign Direct Invesmtent and Productivity Growth: A Survey of Theory, Research paper 2004/15, Research paper Series, Globalisation, Productivity and Technology, The University of Nottingham, Levehulme Center for Globalisation and Economic Policy.

Findlay, R., 1978 "Relative backwardness, direct foreifn investment, and the transfer of technology: a simple dynamic model”, Quarterly Journal of Economics, vol. 92, pp 1-16.

Gershenberg, I., 1987 The Training and Spread of Managerial Know-how: A Comparative Analysis of Multinational and other Firms in Kenya, World Development, vol. 15: pp 931-939.

Girma, S. 2005.'Absorptive Capacity and Productivity Spillovers from FDI. A Threshold Regression Analysis', Oxford Bulletin of Economics and Statistics, 67(3): 281-306 Gorg, H., and Greenaway, D. 2004 Much Ado about Nothing? Do Domestic Firms ReallyBenefit from Foreign Direct Investment? The World Bank Research Observer, vol. 19, no. 2, pp 171-197. 
Gorg, H., and Strobl, E., 2002 Spillovers From Foreign Firms Through Worker Mobility: An Empirical Investigation, Institute for the Study of Labour (IZA), Germany, Discussion Paper Series, Discussion Paper No. 591, October.

Gorg, H., Strobl, E. and Walsh, F., 2002 Why Do Foreign-Owned Firms Pay More?: The Role of On-the-Job Training, Institute for the Study of Labour (IZA), Germany, Discussion Paper Series, Discussion Paper No. 590.

ILO 1981 Multinationals' Training Practices and Developments, Geneva: International Labour Office.

Jovanovic, B., 1997 Learning and growth, in Advances in Economics II, Kreps, D., and K., Wallis (eds.) Cambridge University, pp 318-339

Kinoshita, Y. 1998 Firm Size and Determinants of Foreign Direct Investment, Paper presented at the Eastern Economic Association and Japan Economic Seminar, University of Columbia, December, JEL classification F23, L60, O53

Koizumi, T., and Kopecky, K.J., 1977 "Economic growth, capital movements and the international transfer of technical knowledge," Journal of International Economics, vol. 7, pp 45-65.

Kokko, A., 1994 Technology, market characteristics and spillovers, Journal of Development Economics, 43, pp 279-293.

Lindsey, C., W., 1986 Transfer of Technology to the ASEAN Region by US Transnational Corporations, ASEAN Economic Bulletin, vol. 3: pp 225-247.

Lipsey, R. 2000 "Inward FDI and economic growth in developing countries", Transnational Corporations, 9(1): pp 66-95

Narula, R. and Marin, A., 2003 FDI spillovers, absorptive capacities and human capital development: evidence from Argentina, Infonomics Research Memorandum Series 2003-16, Maastricht Economic Research Institute on Innovation and Technology, The Netherlands, http://www.merit.unimaas.nl.

Obwona, M. 2004 Foreign direct investment in Africa, in Financing Pro-poor growth in Africa, Proceedings of AERC Senior Policy Seminar VI, Kampala, Uganda. 
Sousa, N., 2001 Multinationals and Technology Transfer through Labour Training, Mimeo, University of Nottingham (presented at CEPR Workshop on "Labour Markets Effects of European Foreign Investments", Dublin, July 2001).

Todaro, M.P., 1981 Economic Development in the Third World, Longman, London.

UNCTAD 1999 Foreign Direct Investments in Africa: Performance and Potentials, UNCTAD/ITE/IIT/Misc. 15, www.unctad.org/en/docs/poiteiitm15.pdf

Vo, X. V. and Batten, J.A. 2006 The Importance of Social Factors when assessing the Impact of Foreign Diect Investment on Economic Growth, paper presented at the 2006 Academy of International Business Conference, Beijing, China and the 2006 Asian Finance Conference, Auckland NZ.

Wang, J.Y., and Blomstrom, M., 1992 Foreign Investment and Technology Transfer: A Simple Model, European Economic Review, 36(1): pp 137-55.

Yauri, N.M. 2006 Foreign Direct Investment and Technology Transfer to Nigerian Manufacturing firms: Empirical from Empirical Data, Central Bank of Nigeria Economic and Financial Review, Vol. 44, No. 2: pp 18-38.

Table 1: Sectoral Contribution to GDP, 1960-2000 (Percent)

\begin{tabular}{lrrrrrr} 
Sector & 1960 & 1970 & 1980 & 1990 & 2000 & 2002 \\
\hline & & & & & & \\
Agriculture & 64.1 & 47.6 & 30.8 & 39.0 & 35.7 & 28.4 \\
Manufacturing & $\mathbf{4 . 8}$ & $\mathbf{8 . 2}$ & $\mathbf{8 . 1}$ & $\mathbf{8 . 2}$ & $\mathbf{3 . 4}$ & $\mathbf{5 . 5}$ \\
Crude petroleum & 0.3 & 7.1 & 22 & 12.8 & 47.5 & 40.6 \\
Other sectors & 30.8 & 37.1 & 39.1 & 40.0 & 13.4 & 25.6 \\
& & & & & & \\
\hline
\end{tabular}

Source: Adedipe (2004) 
$\begin{array}{ll}\text { Business Review - Volume } 4 \text { Number } 2 & \text { July - December } 2009\end{array}$

Table 2: OLS regression results on the relationship between FDI, domestic firms and labour productivity

Dependent Variable: Labour Productivity

\begin{tabular}{|c|c|c|c|c|}
\hline Ind. Variables & 1990 & 1994 & 1998 & 2000 \\
\hline \multirow[t]{2}{*}{ fdistartup } & -744144.6 & -1123929 & -225053 & 571123.9 \\
\hline & 581921 & 894709.7 & 513708.7 & 555522.1 \\
\hline \multirow{2}{*}{ fdisurvey } & 1190728 & $1572964 * * *$ & $2303041 * * *$ & $62508^{* * * *}$ \\
\hline & 866145 & 719432.3 & 628118.2 & 578571.4 \\
\hline \multirow[t]{2}{*}{ firmage } & -67070.56 & -51621.12 & -25100.27 & $-29248.48 * *$ \\
\hline & 51450.56 & 36767.07 & 18113.51 & 14268.7 \\
\hline \multirow[t]{2}{*}{ sector2 } & & $-3197104 * * *$ & $-33003884 * * *$ & $-3201017 * * *$ \\
\hline & & 1518736 & 768285.1 & 866709.4 \\
\hline \multirow[t]{2}{*}{ sector4 } & & $-2498351 * * *$ & $-4018323 * * *$ & $-4645537 * * *$ \\
\hline & & 839471.4 & 806211.8 & 943810.8 \\
\hline \multirow[t]{2}{*}{ sector6 } & & -744180.7 & $-2162882^{* * *}$ & $-2590698 * * *$ \\
\hline & & 1753192 & 993068.4 & 977297.6 \\
\hline \multirow{2}{*}{ sector7 } & & -1676616 & $-2369451 * *$ & $-2610239 *$ \\
\hline & & 1163267 & 1222342 & 1522057 \\
\hline \multirow[t]{2}{*}{ sector8 } & & $-1633462 * * *$ & -1448607 & $-2741373 * * *$ \\
\hline & & 631633.9 & 10980333 & 773351.3 \\
\hline \multirow[t]{2}{*}{ sector9 } & & $-2368823^{* * *}$ & $-1972716^{* *}$ & $-2499747 * *$ \\
\hline & & 809269.8 & 11109978 & 1141563 \\
\hline \multirow[t]{2}{*}{ sector11 } & & $-2623155^{* * *}$ & $-2695362 * * *$ & $-2616155^{* * *}$ \\
\hline & & 917856 & 824215 & 862186.6 \\
\hline \multirow[t]{2}{*}{ sector12 } & & $-1940627^{* * *}$ & $-2653043^{* * *}$ & $-25810337 * * *$ \\
\hline & & 790346.3 & 873362.2 & 889562.9 \\
\hline \multirow[t]{2}{*}{ sector13 } & & $-1924990 * *$ & $-1822781 * *$ & $-3136735 * * *$ \\
\hline & & 1022868 & 1060169 & 913352.5 \\
\hline \multirow[t]{2}{*}{ Region2 North } & 418373.3 & -338112.4 & 103452.5 & -703714.8 \\
\hline & 339512.6 & 819376.7 & 654974.7 & 777708.7 \\
\hline Region3 & 1540987 & 739696.7 & 160037.7 & -904914.3 \\
\hline Lagos/South & 1257290 & 1356044 & 636701.5 & 749760.9 \\
\hline \multirow[t]{2}{*}{ firmsize } & -656181.7 & -349705.2 & -31664.37 & 379238.4 \\
\hline & 511644.6 & 515674.9 & 546757.1 & 554105.1 \\
\hline F statistic & 0.51 & $1.96 * *$ & $4.70^{* * *}$ & $3.91 * * *$ \\
\hline R squared & 0.1020 & 0.1976 & 0.3096 & 0.3703 \\
\hline Constant & 1255157 & 3414438 & 3667890 & 4586250 \\
\hline
\end{tabular}

$*, * *, * * *=$ Significant at $10 \%, 5 \%$ and $1 \%$ level respectively. 
Table 3: Identity of Sectors of Sample Firms

\begin{tabular}{ll} 
Sector identification & Name of sector \\
\hline sector1 & Food and beverages \\
sector2 & Wood and furniture \\
sector4 & Textile and garments \\
sector6 & Metal \\
sector8 & Paper/printing/publishing \\
sector9 & Non-metal \\
sector12 & Pharmaceuticals \\
sector13 & Plastics \\
\hline
\end{tabular}

\section{Bribing the Knowledge Worker}

What we call the Information Revolution is actually a Knowledge Revolution. What has made it possible to routinize processes is not machinery; the computer is only the trigger. Software is the reorganization of traditional work, based on centuries of experience, through the application of knowledge and especially of systematic, logical analysis. The key is not electronics; it is cognitive science. This means that the key to maintaining leadership in the economy and the technology that are about to emerge is likely to be the social position of knowledge professionals and social acceptance of their values.

P.F. Drucker: Managing in the Next Society, pp. 22-23 